TERMINUS

t. 19 (2017), z. 3 (44), s. $477-510$

doi:10.4467/20843844TE.17.014.8881

www.ejournals.eu/Terminus

\author{
Jakub Niedźwiedź \\ Uniwersytet Jagielloński \\ jakub.niedzwiedz@uj.edu.pl
}

\title{
Polska szesnastowieczna propaganda wojenna w działaniu: przypadek Atlasu Księstwa Połockiego (1580) ${ }^{1}$
}

\section{Abstract \\ Polish $1^{\text {th }}$-century War-Time Propaganda in Action: The Case of Atlas Księstwa Połockiego (1580)}

The paper's objective is to demonstrate: a) Stanisław Pachołowiecki's Atlas Księstwa Połockiego (Rome 1580) as the first part of a major propaganda action conducted by the royal chancellery; b) the course of its publication; $c$ ) who was engaged in its production. At first, the author reminds that Atlas was made during the Livonian War. The main commissioners were King Stephen Báthory and Chancellor Jan Zamoyski. The next part presents the chief propagandistic text created by the Polish chancellery, Edictum regium de supplicationibus, printed in Polatsk in early September 1579. It is an account of the circumstances of the capture of the city by Stephen Báthory's army. The author reviews the text's distribution and translation into English among other languages. It turns out that Edictum, issued several times in 1579, provides the most significant context for the Atlas. The author argues e.g. that the

${ }^{1}$ Artykuł powstał $\mathrm{w}$ ramach projektu badawczego Narodowego Centrum Nauki Opus (nr 2014/15/B/HS2/01104) Zwiazki literatury polskiej $i$ kartografii $w$ XVI - I poł. XVII w. Autor pragnie gorąco podziękować dr. hab. K. Łopateckiemu i dr. G. Franczakowi za cenne uwagi i korektury wniesione do artykułu. 
Atlas was to be a commentary for the edict. Next, the process of the publication of maps is explained. The author discusses the circumstances in which the decision to publish them was made, as well as the criteria for selecting cartographic material and the final redaction. He then indicates who was responsible for delivering the text to Rome, when it happened, who was engaged in its publication, and when it was published. The comparison of the dates of the Atlas's shipment to Rome and publication of other texts enables the author to hypothesise about a coherent propaganda action. He shows that its aim was, above all, to win foreign public opinion. In result, several different types of texts were created: a historical narrative (Edictum two different Polish editions), a collection of maps (Atlas), a Latin panegyric speech by A. Patrycy Nidecki and a Latin and a Polish odes by J. Kochanowski. The last part of the paper presents the connections between various persons forming the human network directly or indirectly related to the publication of the Atlas and the Polish propaganda action.

Keywords: history of cartography, Renaissance cartography, atlas, Polish Renaissance literature, Jan Zamoyski, Stephen Báthory, Polish-Lithuanian Commomwealth, Russia, Polotsk, Livonian War, political propaganda in the $16^{\text {th }}$ century, Atlas Ksiestwa Połockiego, history of printing

\section{Wstęp}

Atlas Księstwa Połockiego jest zbiorem ośmiu miedziorytniczych map powstałych w czasie wojny Rzeczypospolitej z Moskwą (wojny inflanckiej) prowadzonej w latach 1579-1582. Jedna przedstawia tereny fragmentu województwa witebskiego i połockiego, określanych na mapie jako Księstwo Połockie. Na drugiej ukazany jest widok jego stolicy, Połocka, wraz z rozmieszczeniem wojsk polsko-litewsko-węgierskich oblegających miasto w sierpniu 1579 roku. Na sześciu pozostałych znajdują się widoki sześciu miast i twierdz zdobytych przez oddziały Stefana Batorego latem i jesienią 1579 roku. Mapy te stanowią element kampanii propagandowej Rzeczypospolitej przeciw Moskwie. Celem tej akcji było przedstawienie racji króla polskiego i Rzeczypospolitej, a kampania była prowadzona równolegle z działaniami wojennymi. Atlas, którego autorem jest sekretarz 
królewski Stanisław Pachołowiecki, został wydany w Rzymie przez Giovanniego Battistę Cavalieriego w 1580 roku. Dysponujemy wieloma źródłami, które mówią o procesie powstawania i publikacji Atlasu. Wiemy dzięki nim, kto był zaangażowany w to przedsięwzięcie. Wiemy też, jaki był zasięg oddziaływania publikacji mówiących o polsko-litewskich zwycięstwach. Atlas jest więc bezprecedensowym przedsięwzięciem w historii polskiej kartografii, książki oraz propagandy politycznej w XVI wieku. Celem niniejszego artykułu jest próba pokazania, jakie były okoliczności publikacji map Pachołowieckiego. Zamierzam odpowiedzieć na trzy pytania:

1. Jak się przedstawia ta publikacja na tle europejskiej kampanii propagandowej prowadzonej przez polską kancelarię?

2. Jak przebiegał proces wydawania Atlasu?

3. Kto był zaangażowany w powstanie Atlasu i jak działał human network wokół tej publikacji?

\section{Wojna propagandowa Rzeczypospolitej przeciw Moskwie}

Głównym źródłem informacji o zdobyciu Połocka 30 sierpnia 1579 roku był łaciński edykt króla polskiego, Stefana Batorego. Publikacja ta, wydana w Warszawie jesienią 1579 roku wraz z dwiema innymi oficjalnymi relacjami $\mathrm{z}$ wojny, była kolportowana $\mathrm{w}$ różnych krajach Europy. Mapy Pachołowieckiego oraz inne publikacje, przede wszystkim poetyckie, były dodatkowymi elementami propagandowymi. Aby więc zrozumieć, jaką rolę odgrywał Atlas, należy najpierw prześledzić, jaki zasięg miała główna publikacja kancelarii wydana po zdobyciu Połocka - Edictum regium de suplicationibus ob captam Polociam. Edykt został wystawiony w Połocku 31 sierpnia 1579 roku i wydrukowany w pierwszych dniach września w drukarni 
polowej Walentego Łapki². Tekst ten został natychmiast wyekspediowany do Wilna, skąd rozsyłano go dalej po całej Rzeczypospolitej i Europie ${ }^{3}$. W ciągu kilku tygodni dotarł również do Anglii.

Późną jesienią 1579 lub zimą 1580 roku ukazała się w Londynie kilkustronicowa broszura o długim i szczegółowym tytule, który w przekładzie na polski brzmi: „Prawdziwa relacja o wzięciu wielkiego miasta i zamku Połocka przez króla Polski oraz o sposobie ataku, rozstawienia artylerii, pracach minerskich, potyczkach i materiałach zapalających, co miało miejsce od 11 sierpnia do 30 tego samego miesiąca 1579 roku"4. Relacja ta przyciągała uwagę badaczy przeszłości od wielu lat. Historycy Wysp Brytyjskich wymieniają A True reporte $\mathrm{w}$ kontekście innych tego typu publikacji i zwracają uwagę na to, że jest to jedna z pierwszych relacji wojennych w Ang-

${ }^{2}$ Drukarnia Łapki była filią krakowskiego wydawnictwa Mikołaja Szarffenberga i działała na podstawie specjalnego przywileju Stefana Batorego z 1577 roku. Od tego czasu do roku 1582 Łapka towarzyszył kancelarii koronnej i publikował zarządzenia królewskie i inne teksty (m.in. propagandowe wiersze Kochanowskiego). Za swoją działalność i udział w działaniach wojennych uzyskał w 1581 roku szlachectwo. Zob. A. Kawecka-Gryczowa, Dzieje „Drukarni latającej”. Działalność $i$ wędrówki, „Rocznik Biblioteki Narodowej” 7 (1971), s. 355-357, 361-363. Alodia Kawecka-Gryczowa przypuszcza, że edykt spod Połocka mógł mieć również wersję polską.

${ }^{3}$ O tempie powstania i dystrybucji Edictum regium sporo mówi list biskupa kujawskiego Hieronima Rozdrażewskiego skierowany do Marcina Kromera i datowany w Wilnie 4 września 1579 roku, ale najprawdopodobniej napisany po 11 września (wspomniane jest w nim zdobycie Sokoła), a skończony przed 18 września. Biskup pisze, że przesyła Kromerowi kopię drukowanego edyktu o zdobyciu Połocka. Oznacza to, że druk musiał powstać w pierwszej połowie miesiąca, a zapewne w pierwszych jego dniach. Zob. Korespondencja Hieronima Rozrażewskiego, t. 1: 1567 - 2 VII 1582, wyd. P. Czeplewski, Toruń 1937, s. 297 (poz. 227).

${ }^{4}$ A True reporte of the taking of the great towne and castell of Polotzko by the King of Polonia with the manner of the assaults, batteries, undermininges, skirmishes and fyreworkes, that were there vsed from the 11 of August to the 30 of the same month 1579, [London: s.n.], 1579. Współczesne wydanie: The Taking of Polack - 1579. Elizabethan Newssheet, „The Journal of Belarusian Studies” 1 (1965), no. 1, s. 16-22. 
lii elżbietańskiej5. Podkreślają więc przede wszystkim wymiar informacyjny tej publikacji. Z kolei historycy dziejów dawnej Rzeczypospolitej zauważają, że jest to nie tylko tekst informacyjny, ale również propagandowy. Oba ujęcia $A$ True reporte są w zasadzie od siebie odseparowane. Badacze anglosascy pytają, jak ten tekst działał w Anglii, bez wykazywania większego zainteresowania, do czego się odnosił. Z kolei historyków polskich i białoruskich zajmowało raczej to, że publiczność międzynarodowa była ciekawa wydarzeń na pograniczu litewsko-moskiewskim, jednak bez uwzględnienia kontekstu społecznego i kulturowego, w jakim te wiadomości były kolportowane $\mathrm{w}$ Anglii. Innymi słowy każda $\mathrm{z}$ grup historyków zainteresowana jest sobą i swoją własną przeszłością, utrwalając tym samym istniejącą od ponad stu lat „żelazną kurtynę”. Nie chciałbym tu jednak pisać o różnicach w podejściu do historii Europy obu społeczności naukowych, ale spróbować połączyć te dwa różne spojrzenia.

David Ryndell, autor monografii poświęconej wczesnym gazetom angielskim, przypuszcza, że pierwsze tego typu publikacje (w tym relacja o zdobyciu Połocka) są w istocie listami lub relacjami, do których mechanicznie dodano kartę tytułową. Co więcej, zakłada on, że pierwotnie były to relacje rękopiśmienne ${ }^{6}$. W przypadku relacji o zdobyciu Połocka jest jednak inaczej. Jej pierwotnym źródłem był wspomniany edykt króla Stefana Batorego, pisany jeszcze w obozie wojennym i wydrukowany najpierw w Połocku, a niedługo później w Warszawie ${ }^{7}$. Ten łaciński druk przynosił oficjalną relację o przebiegu oblężenia i stał się bezpośrednim lub pośrednim źródłem dla większości, jeśli nie

${ }^{5}$ Zob. N. Mears, Queenship and Political Discourse in the Elizabethan Realms, Cambridge 2005, s. 151; D. Randall, Credibility in Elizabethan and Early Stuart Military News, London-New York 2015, s. 84-85, 112-113.

${ }^{6}$ D. Randall, Credibility..., s. 84.

7 Edictum regium de supplicationibus ob rem bene adversus Moschum gestam, Kraków: Mikołaj Szarffenberg, 1579. Mimo że druk ukazał się w Warszawie, jako miejsce wydania został podany Kraków, ponieważ tam mieściła się główna siedziba wydawnictwa Szarffenberga. 
wszystkich, późniejszych relacji z przebiegu oblężenia. A True reporte jest przekładem pisma wypuszczonego przez kancelarię króla Stefana Batorego i sygnowanego nazwiskiem władcy ${ }^{8}$.

Czytelnicy angielscy mogli być zainteresowani wojną w północnych regionach Europy głównie za sprawą założonej w 1555 roku przez kupców londyńskich Kompanii Moskiewskiej. W latach 50. i 60. Kompania prowadziła aktywną działalność handlową w państwie moskiewskim dzięki przywilejom wydanym przez Iwana Groźnego. Świadectwem tych działań są relacje Antony’ego Jenkinsona (1529-1610/1611) z wypraw w latach 1558, 1561 i 1571, jego mapa Moskwy wydana w Londynie w 1562 roku$^{9}$, a także listy i relacje innych agentów angielskich działających w państwie moskiewskim. Jednym z nich był Henry Lane.

W 1579 roku lub na początku lat 80. napisał on list do Richarda Hakluyta (ok. 1552-1616), autora wielotomowego dzieła poświęconego angielskim odkrywcom w XVI i na początku XVII wieku. List Lane'a jest ciekawy z tego względu, że pokazuje konflikt między Rzecząpospolitą a Moskwą z punktu widzenia Anglika. W pierwszej części Lane opisuje przebieg poselstwa rosyjskiego do królowej

${ }^{8}$ Tekst angielski jest typowym przykładem wczesnonowożytnego tłumaczenia. Anonimowy tłumacz swobodnie podchodził do oryginalnego tekstu. Pierwotna, łacińska relacja utrzymana była w pierwszej osobie liczby pojedynczej, gdyż narratorem był król. W wersji angielskiej narracja jest trzecioosobowa. Tłumacz wprowadził nieduże skróty, ale zasadniczo treść obu druków jest identyczna. W relacji przeważają niemieckie toponimy, np. stolica Wielkiego Księstwa Litewskiego Wilno, występująca w łacińskim oryginale jako Vilna, pojawia się w wersji angielskiej jako Wilde, czyli po niemiecku. Podobnie zapisywana jest nazwa Połock. W wersji łacińskiej mamy zapis Polotia, w wersji angielskiej pisownia jest niemiecka: Polotzko. Ortografia toponimów jest świadectwem tego, że mimo bezpośrednich kontaktów Anglików z Moskwicinami nadal głównym źródłem angielskiej wiedzy na temat wschodniej Europy pozostawali niemieckojęzyczni kupcy z portów Morza Bałtyckiego i Morza Północnego.

9 A. Jenkinson, Nova absolutaque Russiae Moscoviae et Tartariae descriptio, London: Clement Adams, 1562. Jedyny zachowany egzemplarz editio princeps: Biblioteka Uniwersytetu Wrocławskiego, sygn. 9590-IV.C. 
Elżbiety I w 1567 roku w sprawie relacji między obu krajami. Angielski kupiec podkreśla bardzo mocno, że relacje te były solą w oku króla Zygmunta Augusta. Na dowód tego przesłał kopię listu polskiego władcy do królowej. Odnosząc się do tego listu, Lane nadmienił, że kiedy prowadził interesy w Antwerpii i Amsterdamie w 1566 roku, miał możliwość rozmowy z „Polakami, gdańszczanami i mieszkańcami Wschodu”. „Ponieważ byłem księgowym w Rosji - zauważa mogłem lepiej odpowiedzieć i udowodnić, że ich własne narody [tj. mieszkańcy Rzeczypospolitej - J.N.] oraz Włosi byli winni oskarżeniom napisanym przez króla Polski”"10.

W drugiej części listu Lane relacjonował przebieg konfliktu między Rzecząpospolitą a Moskwą: przypomniał zdobycie przez Moskwicinów Smoleńska w 1514 roku, a przede wszystkim Połocka w roku 1563. Wspomniał o panującym przekonaniu o małej skuteczności Zygmunta Augusta w relacjach z Moskwą, ale też skrytykował Polaków: „W czasach Zygmunta Rosjanie mogli szydzić z Polaków, ponieważ ci uwielbiali spędzać czas w domu ze swoimi żonami, pić i nie słuchać swojego króla"11. List kończy się zdaniem, w którym Lane informował, że niedawno wybrany przez Polaków król Stefan Batory „Odzyskał Połock w roku 1579”'12.

Jest bardzo prawdopodobne, że informacje o zdobyciu Połocka Lane uzyskał ze wspomnianej broszurki A True reporte. Przedrukowany przez Hakluyta list Lane’a pokazuje, jak kolportowane przez

10 „By reason I had bene a lidger in Russia, I could the better reply and proue, that their owne nations and the Italians were most guiltie of the accusations written by the king of Poland". A letter of M. Henrie Lane to M. Richard Hakluit, concerning the first ambassage to our most gracious Queene Elizabeth from the Russian Emperour anno 1567, and other notable matters incident to those places and times, w: R. Hakluyt, The principal Navigations, Voyages, Traffiques and Discoveriesof the English Nation, vol. 1, London 1809, s. 421 (przel. J.N.).

${ }^{11}$ „In the dayes of Sigismund the Russe would tant the Polacks, that they loued their ease at home with their wiues, and to drinke, and were not at commandement of their king". Ibidem.

${ }^{12}$ „Recouered Polotzko againe in the yere 1579”. Ibidem. 
służby Batorego informacje o walkach na pograniczu moskiewsko-litewskim docierały do międzynarodowej opinii publicznej. Stanowisko Lane’a wyrażone w liście dowodzi jednak, że coraz bardziej aktywnym graczem w działaniach informacyjnych był sam Iwan Groźny. Jego przekaz również docierał do zagranicznej opinii publicznej.

O działaniu rosyjskiej propagandy wspominał sekretarz królewski Jan Piotrowski w swoich relacjach z wyprawy pskowskiej w 1581 roku. Pisał, że 15 lipca król otrzymał obszerny list od Iwana Groźnego:

Skoro król zsiadł z koczego do namiotu, alić Dzierżek przybieżał od Moskiewskiego, oddał jakąś wielką hramotę, jak sztukę kolońskiego płótna; dwiema pieczęciami wielkiemi zapieczętowana była [...]. Śmiał się król, patrząc na pieczęci: „Nigdy nam jeszcze tak długiego listu nie przysłał, zapewne opisuje wypadki, od pierwszego Adama poczynając". Wojewoda wileński rzekł: „Podobno, miłościwy królu, wypisane wszystko, co się jedno od początku tej wojny toczyło"13.

Polscy politycy postanowili niezwłocznie odpisać na pismo cara:

Pan kanclerz [Jan Zamoyski - J.N.] kilka dni teraz w drodze, że nic więcej, jedno replikuje na list Moskiewskiemu. O Jezus! Toć go jeździ: każdą sentencyją, każdy artykuł a contrario pervertit. Będzie miał kniaź co ruminować. Będzie ten list po łacinie, do Rzymu go poślem, żeby był po wszytkim świecie, bo też znać on listy swe, co do nas pisze i odpisy nasze po Niemczech rozsyła ${ }^{14}$.

Wysłanie łacińskiego tekstu do Rzymu gwarantowało jego szerszą dystrybucję w Europie. Świadczą o tym liczne kopie i przekłady sławnej relacji Alberta Schlichtinga o okrucieństwach Iwana Groź-

${ }^{13}$ J. Piotrowski, Dziennik wyprawy Stefana Batorego pod Psków, wyd. A. Czuczyński, Kraków 1894, s. 21-22.

${ }^{14}$ Ibidem, s. 36, podkreślenie - J.N. Zob. J. Niedźwiedź, Źródła, konteksty i okoliczności powstania Ody o zdobyciu Połocka Jana Kochanowskiego, „Terminus” 18 (2016), z. 4 (41), s. 384-386. 
nego ${ }^{15}$. Wiedzieli o tym architekci polskiej propagandy wojennej. Zdawali sobie również dobrze sprawę $\mathrm{z}$ tego, że zwycięstwo informacyjne na arenie międzynarodowej jest nie mniej ważne niż sukces militarny na terenach moskiewskich. Rezultatem tego przeświadczenia są liczne teksty poświęcone wojnie w Inflantach, rękopiśmienne i drukowane, które zachowały się w bibliotekach i archiwach całej Europy. Prócz edyktu królewskiego zaliczają się do nich polskie i łacińskie wiersze oraz mowy kilku pisarzy, w tym Jana Kochanowskiego. Ważnym elementem kampanii propagandowej króla Stefana Batorego i kanclerza Jana Zamoyskiego jest zbiór map przygotowanych przez Stanisława Pachołowieckiego, określany tu jako Atlas Księstwa Połockiego.

\section{Wydanie Atlasu Księstwa Połockiego}

\section{Pomysł edycji}

Król i Zamoyski dysponowali mapami wojskowymi, ale od mapy wojskowej do jej publikacji jest długa droga. Przede wszystkim obaj politycy musieli uświadomić sobie, że kartografię można wykorzystać w celach propagandowych. Decyzja o publikacji map dowodzi

${ }^{15}$ Zob. A. Kappeler, Ivan Groznyj im Spiegel der ausländischen Druckschriften seiner Zeit: ein Beitrag zur Geschichte des westlichen Russlandbildes, Bern-Frankfurt am Main 1972, s. 55-56; H. Grala, Wokół dzieła i osoby Alberta Schlichtinga (przyczynek do dziejów propagandy antymoskiewskiej $w$ drugiej połowie XVI w.), „Studia Źródłoznawcze" 38 (2000), s. 35-37, 42, 48; И.В. Дубровский, Новые документы о России Ивана Грозного, „Русский сборник. Исследования по истории России” 11 (2012), s. 26-41; idem, Новые документы по истории отномений России и Италии при Иване Грозном, „Русский сборник. Исследования по истории России" 14 (2013), s. 7-12; idem, Латинские рукописи сочинений Альберта Шлихтинга, „Русский сборник. Исследования по истории России” 18 (2015), s. 74-217; G. Franczak, Wstęp, w: W. Neothebel, Acrostichis własnego wyobrażenia kniaża wielkiego moskiewskiego, oprac. G. Franczak, Warszawa 2016, s. 13-19. 
dobrej orientacji Batorego i Zamoyskiego $\mathrm{w}$ tej nowej dziedzinie propagandy politycznej.

Mapa jest szczególnie atrakcyjnym sposobem opowiadania o polityce. A także niezwykle skutecznym ${ }^{16}$. Szesnastowieczni politycy szybko zdali sobie sprawę z tego, jak potężnym narzędziem propagandowym może być taka forma przekazu. Już od końca XV wieku duże aglomeracje europejskie mogły się poszczycić drzeworytniczymi widokami pokazującymi ich potęgę. Spory ich zbiór znajduje się w Kronice świata Hartmanna Schedla z 1493 roku. W 1500 roku ukazał się widok Wenecji z lotu ptaka Jacopa de' Barbari, który przyczynił się do upowszechnienia takiego sposobu przedstawiania miast w renesansowej kartografii. Niemałą zasługę w upowszechnieniu widoków miasta miał Sebastian Münster ${ }^{17}$. Oprócz tych „pokojowych” portretów miast zaczęly się pojawiać propagandowe mapy ukazujące triumfy militarne. Szczególnie ważne tego typu publikacje zostały wydane w Niemczech. Często były to widoki oblężeń, na przykład plan oblężenia Frankfurtu z 1552 roku $^{18}$. Taka kombinacja: mapa miasta oglądanego z lotu ptaka połączona $\mathrm{z}$ opisem akcji militarnej i dodatkowo zaopatrzona w glossy i komentarze stała się niezwykle nośnym sposobem informowania o wojnach, ich zwycięzcach i o geografii Europy ${ }^{19}$. Warto tu zaznaczyć, że otwarte bitwy dawały

${ }^{16}$ Zob. J.B. Harley, Maps, Knowledge, and Power, w: idem, The New Nature of Maps. Essays in the History of Cartography, ed. P. Laxton, introd. J.H. Andrews, Baltimore-London 2001, s. 63.

${ }_{17}$ Zob. J. van Putten, Networked Nation. Mapping German Cities in Sebastian Münster's 'Cosmographia', Leiden-Boston 2017, s. 44-88. Mapy fortyfikacji były przedstawiane mimo niebezpieczeństwa wykorzystania tej wiedzy przez wrogów. Zob. K. Łopatecki, Rola map i planów w działaniach taktycznych wojsk polskich i litewskich do poczatku panowania Stefana Batorego, „Terminus” 19 (2017), z. 3 (44), s. 609-663.

${ }_{18}$ Zob. H. Graav, K. Faber, Francofordiae ac emporii Germaniae celeberiimi effigatio, 1552 (British Library, Maps KTop C-24-g18).

19 Zob. Ph. Benedict, Graphic History. The Wars, Massacres and Troubles of Tortorel and Parrissin, Genève 2007, s. 75-121, oraz M. Pollak, Cities at War in Early Modern Europe, New York 2010, s. 109-153; J. Niedźwiedź, Atlas Księstwa Połoc- 
tutaj mniej pola do popisu niż oblężenia. Ostatnim wreszcie typem map propagandowych, cieszącym się dużym uznaniem w XVI wieku, były mapy terytoriów. Często były one drukowane w dużych formatach, jak na przykład mapa Polski Bernarda Wapowskiego (1526), mapa Skandynawii Olausa Magnusa (1539) lub mapa Moskwy Antona Wieda (1555).

W drugiej połowie XVI wieku istniało już kilka sposobów uprawiania kartograficznej propagandy. Wciąż jednak był to w miarę świeży wynalazek. Władcy różnych krajów chętnie po niego sięgali, na przykład Elżbieta I, która nakazała w 1589 roku wymalować w swoim pałacu Whitehall w miejscu otwartym dla publiczności mapę świata z przedstawioną na niej trasą podróży Francisa Drake’a. Pomniejszona wersja tej mapy została umieszczona na srebrnym medalu wybitym w 1580 roku $^{20}$. Analogiczne działania do tych, które podejmowały służby Elżbiety I pod koniec lat 80 ., możemy zauważyć dekadę wcześniej w Polsce.

Prawdopodobnie na pomysł, aby opublikować mapy wojskowe, wpadł albo sam król, albo ktoś z jego bliskiego otoczenia. Sam Batory był żywo zainteresowany kartografią ${ }^{21}$. Jest bardzo prawdopodobne, że drugą osobą, która mogła zainicjować wydanie map, był Jan Zamoyski. Kanclerz osobiście nadzorował działania propagandowe kancelarii koronnej i angażował się w produkcję tekstów informacyjnych, w tym map. Świadczy o tym cytowana wyżej relacja księdza Piotrowskiego z kampanii w 1581 roku, a przede wszystkim list do nuncjusza Caligariego z 20 września 1579 roku. „Chorografiami

kiego Stanisława Pachołowieckiego (1580): propaganda, genologia i tworzenie wiedzy geograficznej, „Terminus” 19 (2017), z. 1 (42), s. 131-137.

${ }_{20}$ Zob. J. Evans, The Silver Medal or Map of Sir Francis Drake, „The Numismatic Chronicle and Journal of the Royal Numismatic Society", Fourth Series, 6 (1906), s. 348-350. Opis i zdjęcie medalu na stronie British Museum: http:// www.britishmuseum.org/research/collection_online/collection_object_details. aspx?objectId=952854\&partId=1 (dostęp: 5.03.2018).

${ }^{21}$ Zob. K. Buczek, Kartografia polska w czasach Stefana Batorego, „Wiadomości Służby Geograficznej" 7 (1933), z. 2, s. 69-70. 
[tj. mapami - J.N.] i innymi [przedstawieniami - J.N.], nad których wyrysowaniem osobiście czuwałem, podzielę się z Waszą Wielebnością" - pisał kanclerz ${ }^{22}$.

Zamoyski odpowiadał nie tylko za działania propagandowe i informacyjne, ale też za służby kartograficzne. Kartograf Stanisław Pachołowiecki był sekretarzem królewskim i w związku z tym bezpośrednio podlegał kanclerzowi. Oprócz Pachołowieckiego $\mathrm{w}$ tworzenie map $\mathrm{z}$ kampanii połockiej zaangażowany był jeszcze włoski inżynier Piotr Frankus. Badacze przypuszczają, że to Frankus sporządził rysunki twierdz zdobytych jesienią 1579 roku, wydane później w Rzymie, jakkolwiek nie tylko on mógł uczestniczyć w ich przygotowaniu ${ }^{23}$. Obaj ci kartografowie brali udział w planowaniu edycji.

\section{Wybór map do publikacji}

Ostateczna decyzja o publikacji zapadła przypuszczalnie w październiku albo listopadzie 1579 roku. Karol Łopatecki wykazuje, że mapy przeznaczone do druku wybrano między 6 października (zdobycie Suszy, która jest przedstawiona w Atlasie) a 13 grudnia 1579 roku (zdobycie Nieszczerdy, której wizerunku w Atlasie nie ma) ${ }^{24}$. Ale pomysł, aby wydać mapy, narodził się znacznie wcześniej.

Pierwotnie wydawcą rycin miał być Piotr Frankus. Już 19 września 1579 roku otrzymał on od króla przywilej na wydanie i sprzedaż widoków oblężenia Połocka, Suszy i innych zamków:

22 „Chorographica atque alia quae effigari curavimus coram Reverendissimae Dominationi Vestrae communicabo”. List J. Zamoyskiego do G.A. Caligariego, Dzisna 20 IX 1579, w: Archiwum Jana Zamoyskiego, kanclerza i hetmana wielkiego koronnego, t. 1: 1553-1579, wyd. W. Sobieski, Warszawa 1904, s. 362 (przeł. J.N.); zob. także: K. Buczek, Kartografia polska w czasach Stefana Batorego, s. 81; K. Łopatecki, Ryciny prezentujace kampanię połocka 1579 roku jako jednolita kompozycja kartograficzna, „Terminus” 19 (2017), z. 1 (42), s. 163.

${ }^{23}$ Zob. K. Buczek, Kartografia polska w czasach Stefana Batorego, s. 81-82,

K. Łopatecki, Ryciny prezentujące kampanię połocka..., s. 160-162.

${ }^{24}$ Zob. K. Łopatecki, Ryciny prezentujące kampanię połocka..., s. 163-164. 
Nasz geometra, Petrus Francus Włoch, towarzyszył nam w wyprawie wojennej, z której wracamy. Wykazał się on wieloma przykładami swojego talentu, wśród nich wiernym planem położenia zamku połockiego oraz jego oblężenia i zdobycia. Ma on zamiar ten plan, plan zdobycia zamku Sokół oraz inne plany odnoszące się do naszej wyprawy wyryć w miedzi, wydrukować odbitki i je rozpowszechniać ${ }^{25}$.

Z przywileju wynika, że Frankus był autorem widoku zdobycia Połocka. Tymczasem na rzymskim miedziorycie jako autor został wymieniony Pachołowiecki. Oznacza to, że kartografowie stworzyli kilka różnych widoków Połocka i jego oblężenia. Potwierdzają to źródła. Do dziś zachowały się trzy widoki oblężenia, dwa drukowane i jeden rękopiśmienny ${ }^{26}$. Mogło być jednak więcej zarówno map, jak i rysunków przedstawiających twierdze zdobyte w trakcie kampanii. Spośród tych wszystkich map i widoków wybrano do publikacji osiem.

Mapy, którymi dysponowali Zamoyski i Batory, służyły w pierwszej kolejności do celów militarnych. Przedstawiały one fragmenty terytorium, na którym toczyły się działania wojenne, oraz plany zamków. Były to mapy wielko- i małoskalowe, ukazywały teatr wojenny z różnych perspektyw kartograficznych. Mogły to być proste schematy fortyfikacji otaczających miasto, widoki oblężenia z rozmieszczeniem wojsk i ze scenkami rodzajowymi oraz mapy większego terytorium, wymagające od twórcy dużej wiedzy i wyobraźni kartograficznej. Ponieważ dysponujemy aż trzema widokami oblę-

${ }^{25}$ Akta Metryki Koronnej co ważniejsze z czasów Stefana Batorego 1576-1586. $Z$ rozprawka na czele: O królu Stefanie jako myśliwcu, wyd. A. Pawiński, Warszawa 1882, s. 66 (przeł. J.N.); K. Łopatecki, Ryciny prezentujące kampanię połocka..., s. 161. Karol Łopatecki zwraca uwagę na to, że cytowany wyżej list do Caligariego powstał dzień po wystawieniu przywileju Frankusowi.

${ }^{26}$ Rysunek w Staatsarchiv Dresden, sygn. Schr. VII, F. 90. Nr. 17a wykonany przez Pawła Zumthorna w Krakowie oraz drzeworyt Georga Macka st., Die Eroberung von Polotsk in Litauen, Nürnberg 1579, Biblioteka Książąt Czartoryskich w Krakowie, sygn. XV-R. 6813. Zob. K. Kozica, Charakterystyka prac kartograficznych Stanisława Pachołowieckiego (1580), „Terminus” 19 (2017), z. 1 (42), s. 52-53. 
żonego Połocka, mamy podstawy do próby odpowiedzi na pytanie, co skłoniło króla i Zamoyskiego do wyboru tych konkretnych przedstawień kartograficznych.

Na dwóch wizerunkach (rysunek Zumthorna z Drezna i norymberski drzeworyt Macka) ukazany został moment decydującego szturmu z 29 sierpnia 1579 roku. Widzimy więc latające pociski zapalające, oddziały podchodzące pod mury, cywilów opuszczających miasto po jego zdobyciu, a także scenki obozowe. Tymczasem na planie Pachołowieckiego nie ma takich szczegółów, przedstawione jest natomiast miasto $\mathrm{w}$ dniu decydującego szturmu oraz rozmieszczenie wokół niego obozów i szyk wojsk ${ }^{27}$. Na widokach sześciu twierdz nacisk położony został na fortyfikacje i inne budynki oraz ukształtowanie terenu, ale nie ma na nich żadnych wojsk i w ogóle ludzi. Pojawiają się natomiast informacje, kiedy dana twierdza została zdobyta przez oddziały Stefana Batorego. Osoby, które dokonywały wyboru rysunków, dążyły więc do ukazania w Atlasie zobiektywizowanej przestrzeni albo sceny teatru wojny. Sam przebieg działań militarnych nie był pierwszoplanowy.

\section{Cel publikacji Atlasu}

Daty zdobycia twierdz są głównym elementem łączącym te mapy $\mathrm{z}$ dokumentami królewskimi informującymi o przebiegu kampanii. Relacja o przebiegu oblężenia Połocka znajdują się we wspomnianym już Edictum regium de suplicationibus ob captam Polociam. Edykt ten został wydany raz w pierwszej połowie września 1579 roku w Połocku i wznowiony kilka miesięcy później ponownie w Warszawie wraz z dwoma innymi dokumentami ${ }^{28}$. Poprzedza go skierowane do wojska Edictum Svirense z 12 lipca 1579 roku. W tym

${ }^{27}$ Zob. K. Łopatecki, Oblężenie i zdobycie warownej twierdzy połockiej przez Najjaśniejszego Króla Polski Stefana - wykorzystanie kartografii podczas planowania taktycznego, „Terminus” 19 (2017), z. 4 (45), s. 725.

${ }_{28}$ Edictum regium Svirense ad milites, ex quo causae suscepti in magnum Moscoviae ducem belli cognoscentur. Edictum regium de supplicationibus ob captam Po- 
edykcie zostały wyłożone powody wszczęcia wojny przeciw Iwanowi Groźnemu. Trzecim tekstem, który został wydany w Warszawie, jest Rerum post captam Polotiam contra Moscum gestarum narratio (Narracja o działaniach przeciwko Moskwicinowi po zdobyciu Połocka). W ten sposób w jednym druku została zrelacjonowana praktycznie cała kampania 1579 roku.

Przypuszczalnie były dwie grupy czytelników, które miały zapoznać się z oficjalną historią wojny. Pierwszą stanowiła szlachta polska i litewska, wezwana na sejm do Warszawy na 22 listopada 1579 roku. Ale nie wszyscy posłowie płynnie posługiwali się łaciną. Dlatego można przypuszczać, że drugą, być może prymarną, grupą była publiczność zagraniczna, głównie elity: politycy, duchowni, humaniści, kupcy i finansiści. Dowodem na to są zagraniczne kopie i wznowienia edyktów. Przedruk dokumentów królewskich dwukrotnie ukazał się w Kolonii w 1580 roku, a w 1582 roku w Rzymie ${ }^{29}$. Ich rękopiśmienne kopie znajdują się ponadto w aktach nuncjatury apostolskiej $^{30}$. Z wersji łacińskiej powstały przekłady na inne języki.

lociam. Rerum post captam Polotiam contra Moscum gestarum narratio, Warszawa: Mikołaj Szarffenberg, 1579.

${ }^{29}$ Edictum Serenissimi Poloniae Regis ad milites, ex quo causae suscepti in $\mathrm{Ma}$ gnum Moscoviae Ducem belli cognoscuntur. Item edictum eiusdem de suplicationibus ob captam Polociam habendis: cum epistola qua ordines ad comitia conuocantur et rerum post captam Polociam gestarum narratione. Hisce adiecta sunt quaedam de Magni Moscoviae Ducis genere, quod se nescio qua autoritate ab Augusto Caesare ducere iactitat, Köln, Maternus Cholinus, 1580; S. Reszka, De rebus gestis Stephani I regis Poloniae [...] contra Magnum Moschorum Ducem narratio, Roma: heredes Antonii Bladii, 1582 (edycję tę opracował i wydał G.M. Bruto pod pseudonimem Flaminius Nobilius); zob. P. Marchesani, La Polonia nella storiografia italiana dei secoli XVI-XVII. I clichés ideologici e la loro evoluzione, „Europa Orientalis” 5 (1986), s. 213; G. Gömöry, The Polish Swan Triumphant. Essays on Polish and Comparative Literature from Kochanowski to Norwid, Newcastle upon Tyne 2013, s. 28-31. Pełny wykaz wydań i przekładów podaje Grzegorz Franczak, Polotia recepta. Mapa Księstwa Połockiego jako tekst propagandowy (w przygotowaniu).

${ }^{30}$ Zob. Relacje nuncjuszów apostolskich i innych osób o Polsce od roku 1548 do 1690, t. 1, wyd. E. Rykaczewski, Berlin-Poznań 1864, s. 307-331. Różnica w zapisie nazw miejscowych w drukach i w egzemplarzach watykańskich może wskazywać na 
Znany jest $\mathrm{z}$ opisów bibliograficznych przekład czeski oraz omawiana wyżej publikacja angielska ${ }^{31}$. Można uznać, że warszawskie wydanie edyktów było znacznym sukcesem edytorskim.

Ukazały się one dokładnie w tym samym czasie, w którym zapadła decyzja o wydaniu map Stanisława Pachołowieckiego. Ostatnia z relacji, Rerum post captam Polotiam narratio, opisuje zdobycie Suszy 6 października, ale nie ma już w niej mowy o zdobyciu Nieszczerdy 13 grudnia 1579 roku $^{32}$. Co więcej, w obu wypadkach organem decyzyjnym była kancelaria koronna, czyli Zamoyski. Można więc przyjąć, że publikacja Atlasu była skoordynowana z wydaniem wszystkich edyktów i miała być ich uzupełnieniem. Narracyjna relacja informowała o przebiegu działań. Mapy pozwalały ulokować te działania w przestrzeni. $\mathrm{Z}$ tego powodu nie było potrzeby umieszczać na mapach obrazów działań militarnych. Czytelnik mógł samodzielnie skorelować wojenną relację z mapami. Możliwe, że mapy Pachołowieckiego nadawały się do tego lepiej niż mapy Frankusa.

Przeznaczenie obu publikacji dla czytelników zagranicznych może być powodem, dla którego zdecydowano się wydać Atlas we Włoszech. Początkowo, jak można to wnosić z cytowanego przywileju, król i Zamoyski zdali się na Frankusa, który przygotowywałby miedzioryty w Polsce. Zgodnie z postanowieniami przywileju włoski inżynier zyskiwał wyłączność na tego typu wydawnictwa na okres pięciu lat. Kiedy mapy były rytowane i drukowane przez Cavalieriego w Rzymie, przywilej więc nadal obowiązywał. Karol Buczek przypuszcza, że król nie wiedział o druku ${ }^{33}$. Jednak zaangażowanie w publikację polskiego ambasadora w Rzymie dowodziłoby raczej

\footnotetext{
to, że nuncjusze otrzymali wersje rękopiśmienne wprost $\mathrm{z}$ kancelarii i nie opierali się na drukach.

${ }^{31}$ Novina jista a pravdiva o dobyti znameniteho zamka a pevnosti velihego mesta [...] Polocka, Praha 1580. Niewykluczone, że Novina jista oraz A True reporte były przekładami z pierwodruku wydanego we wrześniu, nie z edycji warszawskiej.

${ }^{32} \mathrm{~W}$ relacji mowa jest o sejmie w czasie przyszłym, co oznacza, że dokument powstał jeszcze przed 22 listopada.

${ }^{33}$ Zob. K. Buczek, Kartografia polska w czasach Stefana Batorego, s. 82.
} 
zmiany decyzji przez władcę. Frankus nigdy później ze swojego prawa nie skorzystał, co oznacza, że proces wydawniczy odbył się z jego aprobatą lub nie. Dwa lata później został zresztą wynagrodzony przez króla indygenatem, co zapewne było też rekompensatą za niezrealizowaną edycję ${ }^{34}$.

Wydanie map w Rzymie z pewnością ułatwiało ich dystrybucję międzynarodową. Gwarantowało też ich wysoką jakość. Miedziorytnictwo, szczególnie przydatne do drukowania map, w Rzymie stało na bardzo wysokim poziomie. Nie wiadomo, czy Frankus w ogóle był miedziorytnikiem, ponieważ nie znamy żadnych jego prac. W Polsce w owym czasie dominującą techniką graficzną pozostawał drzeworyt i możliwe, że nie miał kto w krótkim czasie wykonać płyt z mapami. Tymczasem w Rzymie o takiego specjalistę nie było trudno. Ponadto w Wiecznym Mieście przebywali ludzie królewscy, którzy mogli dopilnować realizacji tego zadania.

\section{Dostarczenie do Rzymu i publikacja}

Nuncjusz Giovanni Andrea Caligari (1527-1604) w liście datowanym w Warszawie 26 lutego 1580 roku pisał do swojego adresata, sekretarza stanu kurii rzymskiej kardynała Tolomea Gallia (1526-1607), zwanego kardynałem Comensisem ${ }^{35}$ : „Biskup płocki będzie miał wszystkie plany fortec zdobytych przez króla w roku ubiegłym, a także plan przedstawiający układ wojsk oblegających Połock. Przypuszczam, że pokaże je Waszej Eminencji'" ${ }^{36}$. Materiały te były tak ciekawe, że nuncjusz poinformował o tym fakcie swojego zwierzchnika.

34 Zob. K. Łopatecki, Ryciny prezentujące kampanię połocką..., s. 158.

35 Zob. G. Brunelli, Gallio Tolomeo, w: Dizionario Biografico degli Italiani, vol. 51, Roma 1998, http://www.treccani.it/enciclopedia/tolomeo-gallio_\%28Dizionario-Biografico\%29/ (dostęp: 1.06.2018)

36 „Il vescovo di Plozca haverà tutti li disegni delle fortezze espugnate dal Re l'anno passato, et anco il modo et l'ordine dell'assedio di Polozco; credo lo mostrarà a V. S. Illima”. G.A. Caligari, I.A. Caligarii nuntii apostolici in Polonia epistolae et acta 
Wspomnianym biskupem płockim był Piotr Dunin Wolski (1531-1590), znakomicie wykształcony humanista i dyplomata. Jako polski wysłannik niemal trzynaście lat spędził w Hiszpanii (1561-1573), a po powrocie do Polski pełnił funkcję podkanclerzego. W 1576 roku Stefan Batory powierzył mu godność kanclerza koronnego. Niecałe dwa lata później Wolski zrzekł się tego urzędu na rzecz Jana Zamoyskiego ${ }^{37}$. Wolski jest dziś znany nie tylko jako polityk i dyplomata, ale również jako bibliofil. Swoją wielką bibliotekę, liczącą ponad tysiąc dzieł, zapisał w większej części Uniwersytetowi Krakowskiemu. Sprawy publikacji map mogły go w związku z tym żywo interesować.

Wolski jako bliski współpracownik króla w 1579 roku został wysłany z misją obediencyjną do Rzymu, gdzie przebywał do 1582 roku jako poseł rezydujący. Swoją podróż rozpoczął w lipcu 1579 roku $^{38}$, a uroczysty wjazd posła do Wiecznego Miasta odbył się 11 listopa$\mathrm{da}^{39}$. Oznacza to, że to nie Wolski przywiózł mapy do Włoch i że zostały mu one dostarczone później.

Mógł je dostarczyć jakiś anonimowy posłaniec. Ale równie prawdopodobne wydaje się, że mapy przywiózł sekretarz nuncjusza Caligariego, ksiądz Antonio Martinelli z Piacenzy. W połowie grudnia 1579 roku wyruszył on $z$ Warszawy ${ }^{40}$. Martinelli wiózł ze sobą nie tylko listy nuncjusza, ale również pisma innych osób, na przykład biskupa Hieronima Rozdrażewskiego. Z cytowanego listu Caligariego wynika, że nuncjusz dowiedział się o przesyłce map do Rzymu, ponieważ wiózł je jego sekretarz.

1578-1581, ed. L. Boratyński, Cracoviae 1915 (Monumenta Poloniae Vaticana, 4), s. 389, nr 207 (przeł. G. Franczak).

37 Zob. K. Obremski, Wstęp, w: Volsciana. Katalog renesansowego księgozbioru Piotra Dunin-Wolskiego, biskupa płockiego, oprac. A. Obrębski, Kraków 1999, s. 5.

38 Zob. Korespondencja Hieronima Rozrażewskiego, t. 1, s. 290 (poz. 219).

39 Zob. Z dworu Stanisława Hozjusza. Listy Stanisława Reszki do Marcina Kromera 1568-1582, przeł., wstęp i komentarze J.A. Kalinowska, Olsztyn 1992, s. 230 (poz. 184).

40 Zob. Korespondencja Hieronima Rozrażewskiego, t. 1, s. 302 (poz. 232 i 234). 
Mapy trafiły do Wolskiego w pierwszych tygodniach 1580 roku. Polski poseł przypuszczalnie sam miał wpływ na ostateczny kształt publikacji. Kwestie praktyczne i redakcję zlecił jednak Tomaszowi Treterowi (1547-1610), który doskonale nadawał się do tego zadania. Był nie tylko kanonikiem w bazylice Santa Maria in Trastevere oraz pisarzem, ale również rysownikiem i miedziorytnikiem. Zaprojektował i wyrytował między innymi 100 miedziorytów ilustrujących życie jego byłego patrona i pracodawcy, kardynała Hozjusza. W czasie swojego pobytu w Rzymie pozostawał w zażyłych stosunkach z Giovannim Battistą Cavalierim (ok. 1525-1601). Cavalieri i Treter współpracowali co najmniej od 1574 roku. Trzecim ich wspólnym dziełem był właśnie Atlas Księstwa Połockiego ${ }^{41}$.

Na mapie Księstwa Połockiego wyrytowanej przez Cavalieriego Treter dodał skomponowany przez siebie epigramat oraz herb Rzeczypospolite ${ }^{42}$. W ten sposób mapa ta stała się pierwszym panegirykiem wydrukowanym we Włoszech, w którym wychwalano Batorego. W przyszłości Treter i Cavalieri opublikować mieli jeszcze kilka utworów dedykowanych królowi lub pod patronatem królewskim.

Atlas Księstwa Połockiego dotarł do Zamoyskiego nie później niż w drugiej połowie listopada 1580 roku. Pozwala o tym sądzić list Stefana Batorego z 11 grudnia 1580 roku, w którym król pisze o planach wydania mapy Inflant Sulimowskiego:

Ponieważ wiemy, że Wasza Wielmożność ma wydrukowaną mapę terenów, które rekuperowaliśmy w minionym roku, prosimy, aby Wasza Wielmoż-

${ }^{41}$ Szerzej o roli Cavalieriego i Tretera w publikacji Atlasu pisze G. Franczak, Rzymski łącznik. Giovanni Battista Cavalieri (1525-1601), rytownik Hozjusza i Tretera (w przygotowaniu).

${ }^{42}$ Zob. T. Chrzanowski, Działalność artystyczna Tomasza Tretera, Warszawa 1984, s. 19; G. Jurkowlaniec, Sprawczość rycin. Rzymska twórczość graficzna Tomasza Tretera i jej europejskie oddziaływanie, Kraków 2017, s. 215, 216; G. Franczak, Filologia mapy. Badanie dawnej kartografii metoda krytyki tekstu na przykładzie toponimii mapy Księstwa Połockiego S. Pachołowieckiego z 1580 roku, "Terminus" 19 (2017), z. 1 (42), s. 204; J. Niedźwiedź, Atlas Księstwa Połockiego - wprowadzenie, „Terminus” 19 (2017), z. 1 (42), s. 10, 13, 15. 
ność dał nam znać, jeśli uzna, że także ta skorygowana przez Waszą Wielmożność mapa Sulimowskiego może być wydana drukiem ${ }^{43}$.

Biorąc pod uwagę czas przepływu korespondencji między królem a Batorym oraz tempo dostarczania przesyłki z Rzymu na Litwę, gdzie przebywał Zamoyski późną jesienią 1580 roku, można założyć, że mapa była drukowana nie później niż w październiku 1580 roku.

\section{Dystrybucja}

Atlas rozszedł się przede wszystkim we Włoszech. Trzy z zachowanych kompletów mają proweniencję włoską. Drugie wydanie planu oblężenia Połocka świadczy o tym, że publikacja ta musiała się rozprowadzać dość dobrze. Wszystkie trzy ryciny stanu drugiego pochodzą z Włoch. Część egzemplarzy musiała dotrzeć do Polski, o czym świadczy cytowany list Batorego do Zamoyskiego. Jeden komplet Atlasu znany jest z Francji ${ }^{44}$. Propaganda Stefana Batorego znalazła najbardziej podatny grunt we Włoszech. Cavalieri i Treter nie byli jedynymi wydawcami panegiryków ku czci polskiego władcy. Utwory poświęcone Batoremu i jego zwycięstwom nad Moskwą ukazywały się we Włoszech nieprzerwanie aż do jego śmierci. Wśród nich była dwuczęściowa łacińsko-włoska antologia wierszy poetów z Republiki Weneckiej ${ }^{45}$.

43 „Quoniam vero scimus Sinceritatem Vestram descriptionem regionis anno praeterito recuperatae impressam habere, postulamus, ut si videbitur eam quoque descriptionem Sulimovii per Sinceritatem Vestram correctam typis committi, nos certiores faciat". List Stefana Batorego do J. Zamoyskiego, Grodno 11 XII 1580, w: Archiwum Jana Zamoyskiego, kanclerza i hetmana wielkiego koronnego, t. 2: 1580-1582, wyd. J. Siemieński, Warszawa 1909, s. 34 (przeł. J.N.); zob. K. Buczek, Kartografia polska w czasach Stefana Batorego, s. 82.

${ }^{44}$ Proweniencja map: zob. K. Kozica, Charakterystyka prac kartograficznych..., s. $42-50$.

${ }_{45}$ Zob. J. Nowak-Dłużewski, Okolicznościowa poezja polityczna w Polsce. Pierwsi królowie elekcyjni, Warszawa 1969, s. 110-177; A. Kappeler, Ivan Groznyj..., s. 66-69. 


\section{Dopełnienie akcji propagandowej: retoryka i poezja}

Antologia włoskich poetów należała do ostatnich poetyckich publikacji podsumowujących wojnę inflancką. Jedną z pierwszych była krótka mowa napisana przez Andrzeja Patrycego Nideckiego (15221587), kanonika warszawskiego i sekretarza królowej Anny Jagiellonki oraz przyjaciela Jana Kochanowskiego ${ }^{46}$, przede wszystkim jednak humanistę wykonującego różne zlecenia dla Jana Zamoyskiego. 21 listopada 1579 roku Patrycy wygłosił w kolegiacie św. Jana mowę panegiryczną ku czci zwycięskiego króla ${ }^{47}$. Została ona wydana w ciągu paru tygodni w Krakowie przez Jana Januszowskiego, właściciela Drukarni Łazarzowej. Wraz z trzema innymi mowami wygłoszonymi przez Patrycego po sukcesach w 1580 i 1581 roku została ona wznowiona w roku $1583^{48}$.

Kolejnym etapem działań propagandowych było opublikowanie kilka tygodni później wierszy Jana Kochanowskiego. Są to Pieśń o zdobyciu Polocka oraz Ode de expugnatione Polottei ${ }^{49}$. Publikacje te zostały wydane przed 21 lutego 1580 roku w Warszawie przez Walentego Łapkę, tego samego, który drukował edykty pod Połockiem i w Warszawie ${ }^{50}$. Łacińska oda Kochanowskiego była ewidentnie stworzona dla publiczności międzynarodowej, polski wiersz - dla odbiorców z Rzeczypospolitej. Za tym wydaniem ponownie stał Zamoyski. Zachowała się częściowo korespondencja między nim

${ }^{46}$ Zob. K. Morawski, Andrzej Patrycy Nidecki. Jego życie i dzieła, Kraków 1892, s. 284-286.

47 Zob. B. Awianowicz, Wstęp, w: A. Patrycy Nidecki, Trzy mowy gratulacyjne zokazji zwycięstwa nad Moskwicinami, oprac. B. Awianowicz, Warszawa 2016, s. 18.

48 Zob. ibidem, s. 28-29.

49 Zob. P. Buchwald-Pelcowa, Dawne wydania dzieł Jana Kochanowskiego, Warszawa 1993, s. 90. Polska pieśń została później wydrukowana w zbiorze Pieśni ksiąg dwoje (1586) jako pieśń II 13, a łacińska oda kończy zbiór Lyricorum libellus (1580). Zob. J. Niedźwiedź, Źródła, konteksty i okoliczności powstania Ody..., s. 362.

50 Zob. A. Kawecka-Gryczowa, Dzieje „Drukarni latającej”..., s. 363-364. 
a Kochanowskim ze stycznia 1580 roku, z której wynika, że teksty te powstały na zamówienie kanclerza ${ }^{51}$.

Ostatecznie na dużą akcję propagandową poświęconą zdobyciu Połocka złożyło się pięć odmiennych tekstów lub grup tekstów:

1) narracja historyczna (Edictum regium de supplicationibus) Połock, 31 VIII 1579,

2) mowa Andrzeja Patrycego Nideckiego - Warszawa, $21 \mathrm{XI}$ 1579, wyd. Kraków, XII 1579,

3) wydanie wszystkich edyktów - Warszawa, X-XI 1579,

4) Atlas Księstwa Połockiego - redakcja Warszawa (?), X-XI 1579, wyd. Rzym, przed XI 1580,

5) poezje Jana Kochanowskiego - Warszawa, po 14 I przed 21 II $1580^{52}$.

Oprócz tych tekstów powstały utwory, które nie były inspirowane bezpośrednio przez kancelarię: epitalamium Daniela Hermanna zawierające opis zdobycia Połocka (Wilno 1579) ${ }^{53}$, niemiecka gazeta ulotna Georga Macka, w całości poświęcona zdobyciu miasta $(1579)^{54}$, oraz poemat Bazylego Hiacynta z Wilna (Hyacinthiusa, Padwa 1580) ${ }^{55}$. Możliwe, że ten ostatni utwór mógł być inspirowany

${ }^{51}$ Zob. J. Kochanowski, Pieśni trzy... O wzięciu Połocka. O statecznym słudze R.P. O uczciwej małżonce, Warszawa 1583, k. Av. (http://www.polona.pl/dlibra/doc content 2 ?id $=85 \&$ from $=$ editionindex $\&$ from $=-3$ search \&dirids $=20 \&$ lang $=\mathrm{pl}$, dostęp: 28.10.2018); J. Niedźwiedź, Źródła, konteksty i okoliczności powstania Ody..., s. 361, 365-366.

52 Zob. P. Buchwald-Pelcowa, Dawne wydania..., s. 90.

${ }_{53}$ Zob. J. Nowak-Dłużewski, Okolicznościowa poezja polityczna..., s. 112-115.

54 Zob. S. Alexandrowicz, Kartografia Wielkiego Księstwa Litewskiego od XV do połowy XVIII wieku, Warszawa 2012, s. 330, il. 44.

${ }_{55}$ Basilius Hyacinthius Vilnensis, Panegyricus in excidium Polocense atque in memorabilem victoriam Stephani [...] ex potentissimo Moschorum Principe III. Calendis Septembris 1579 reportatam, Padova: Lorenzo Pasquato, 1580. Zob. J. Nowak-Dłużewski, Okolicznościowa poezja polityczna..., s. 121-122, 224. Juliusz Nowak-Dłużewski przypuszcza, że Hyacinthius był jezuitą i że napisał swój utwór na zamówienie przełożonych z Wilna. Chcieli oni okazać wdzięczność królowi, który 1 kwietnia 1579 roku w Wilnie w czasie przygotowań do wojny erygował jezuicki uniwersytet, Akademię Wileńską. Zob. J. Nowak-Dłużewski, Okolicznościowa poe- 
mapą Pachołowieckiego Oblężenie i zdobycie warownej twierdzy potockiej. Opis miasta oraz rozmieszczenia wojsk litewskich, polskich, niemieckich i węgierskich u Bazylego Hiacynta odpowiada widokowi Pachołowieckiego ${ }^{56}$.

Król i kanclerz byli na tyle zadowoleni z publikacji Atlasu Księstwa Połockiego, że wzięli pod uwagę możliwość wydania dalszych map. Król wspomina o planach druku mapy Inflant Sulimowskiego. Wysłano ją do Rzymu, ale nigdy nie została opublikowana ${ }^{57}$. Przypuszczalnie za zgodą Zamoyskiego niektóre z map wojskowych zostały przekazane Gerardowi Merkatorowi. Dwie z nich ukazały się w jego Atlasie w 1595 roku: mapa Inflant Macieja Strubicza oraz mapa obszaru między Moskwą a Nowogrodem (Russiae pars amplificata), a także geograficzny opis Inflant przygotowany przez Strubicza, a wydany dopiero w $1727 \mathrm{roku}^{58}$.

Publikacja kolejnych map miała być częścią drugiej zmasowanej akcji propagandowej. Przypadała ona na lata $1582-1584$. W tym czasie wydano jeszcze więcej tekstów o całej wojnie inflanckiej. Zaliczają się tu dzieła historyczne, poezje, mowy, utwory muzyczne, medale i mapy ${ }^{59}$. Nawet te późniejsze teksty zawierają odniesienia do

zja polityczna..., s. 224; L. Piechnik, Poczatki Akademii Wileńskiej 1570-1599, foreword J.W. Woś, Roma 1984, s. 53-60. Jednak sam druk nie potwierdza przynależności Hyacinthiusa do Towarzystwa Jezusowego, co więcej, utwór jest dedykowany jednemu z czołowych kalwinistów litewskich, na co jezuici raczej by się nie zgodzili.

${ }^{56}$ Zob. Basilius Hyacinthius Vilnensis, Panegyricus..., s. C3v.-C4r.

${ }^{57}$ Możliwe, że mapa Sulimowskiego nie została wydana, ponieważ przedstawione na niej ziemie $\mathrm{w}$ większości nie przypadły Litwie. Za spostrzeżenie to serdecznie dziękuję prof. Karolowi Łopateckiemu.

${ }^{58}$ Zob. M. Strubicz, Brevis atque accurata Livonice Ducatus descriptio historico-geographica, ed. J.L. Diezius, Amsterdam: Abraham Strander, 1727. Warto dodać, że mapa Inflant Strubicza ukazała się po raz pierwszy w 1589 roku w Polonii Kromera. Zob. K. Łopatecki, Wykorzystanie map w działaniach strategicznych do 1586 roku w Koronie i Wielkim Księstwie Litewskim, „Terminus” 19 (2017), z. 3 (44), s. 511-566.

${ }^{59}$ Spośród ważniejszych tekstów należy wymienić: J. Kochanowski, Ad Stephanum Bathorrheum regem Poloniae inclytum Moscho debellato et Livonia recuperata epinicion, Kraków: Drukarnia Łazarzowa, 1583; S. Reszka, De rebus gestis Stephani I...; F. Gradowski, Hodoeporicon Moschicum, Wilno: Daniel Łęczycki, 1582; 
kampanii 1579 roku. Znajdziemy je na przykład we włoskim zbiorze Viridarium poetarum - Giardino de’ poeti z 1583 roku oraz w Jeździe do Moskwy Kochanowskiego z roku 1583:

Tam kniaź Połocko stracił, Sokół z perzynami

Aż pod niebo wyleciał wespół z obrońcami.

Susza wyschła, Sytna zbył, Krasne padły ściany,

Turowla już nie jego, Nieszczerda, Kosiany ${ }^{60}$.

\section{Sieć powiązań (human network) autorów Atlasu}

Dzięki bezpośrednim i pośrednim źródłom jesteśmy w stanie odpowiedzieć na dwa pytania: kto brał udział w stworzeniu takiego przekazu propagandowego i jaką rolę odgrywali poszczególni uczestnicy tego przedsięwzięcia. Przygotowanie i wykonanie tak złożonego projektu wymagało zaangażowania wielu ludzi o różnych kompetencjach. Atlas pozwala zrekonstruować sieć powiązań międzyludzkich, bez której doprowadzenie przedsięwzięcia do końca nie byłoby możliwe. Mapy były jednak częścią większej akcji propagandowej, więc sieć należy poszerzyć o osoby, które nie były związane bezpośrednio z powstaniem Atlasu.

Osoby należące do tej sieci możemy podzielić na cztery główne grupy:

J. Kochanowski, Jezda do Moskwy, Kraków: Drukarnia Łazarzowa, 1583; Viridarium poetarum, Venezia: Joannes Gryphius, 1583; Giardino de poeti, Venezia: fratelli Guerra, 1583; R. Heidenstein, De bello Moscovitico commentatorium libri sex, Kraków: Drukarnia Łazarzowa, 1584; A. Rymsza, Deketeros akroama, Wilno: Daniel Łęczycki, 1585. W 1582 roku wybito medal upamiętniający odzyskanie Połocka oraz Inflant. Zob. G. Franczak, Polotia recepta... (w przygotowaniu). Epinicjon Kochanowskiego był wykonywany do muzyki w czasie wesela Jana Zamoyskiego w 1583 roku.

${ }_{60}$ J. Kochanowski, Jezda do Moskwy, w: idem, Poematy okolicznościowe, oprac. R. Krzywy, Warszawa 2018, s. 268 (w. 151-154). 
1) politycy - główni aktorzy i beneficjenci przedsięwzięcia,

2) sekretarze - autorzy tekstów i map,

3) zewnętrzni podwykonawcy i klienci,

4) krąg osób zewnętrznych.

W skład pierwszej grupy wchodzą król, jako główny zleceniodawca, oraz Jan Zamoyski - jako zleceniodawca i „redaktor naczelny”. Zaliczają się do niej ponadto: biskup Piotr Wolski, poseł polski do Rzymu, pośrednik w wydaniu publikacji, a także nuncjusz Giovanni Andrea Caligari i kardynał Gallio. Byli zainteresowani dostępem do materiałów kartograficznych, o czym świadczy list Zamoyskiego.

Drugą grupę stanowią przede wszystkim sekretarze królewscy, wśród nich kartografowie. Ich bezpośrednim przełożonym był Zamoyski, odpowiedzialny za służby kartograficzne. Prócz Piotra Frankusa i Stanisława Pachołowieckiego należy wymienić Macieja Strubicza. Zachowała się korespondencja między kanclerzem a Strubiczem, który przygotowywał mapy na potrzeby wojny z Moskwą ${ }^{61}$. Sekretarzami królewskimi byli również Jan Kochanowski i Andrzej Patrycy Nidecki. Wprawdzie nie pracowali już oni w kancelarii, ale nadal mieli tytuł sekretarza i przede wszystkim wykonywali różne zlecenia dla Zamoyskiego. Teksty Nideckiego i Kochanowskiego stanowiły literackie dopełnienie dotychczasowych relacji i map.

Do trzeciej grupy zaliczają się wykonawcy ostatecznych wersji map przeznaczonych do dystrybucji. Są to przede wszystkim Treter i Cavalieri. Oprócz nich należy wymienić Walentego Łapkę, szefa przenośnej drukarni, która publikowała oficjalne dokumenty królewskie i wiersze Kochanowskiego, a także Jana Januszowskiego, drukarza z Krakowa, który wydawał utwory Nideckiego i Kochanowskiego.

${ }^{61}$ Zob. K. Buczek, Dorobek kartograficzny wojen Stefana Batorego, „Wiadomości Służby Geograficznej” 8 (1934), z. 3, s. 14; S. Alexandrowicz, Kartografia Wielkiego Księstwa Litewskiego..., s. 62-63; K. Łopatecki, Wykorzystanie map w działaniach strategicznych do 1586 roku..., s. 511-566. 
Do grupy czwartej zaliczają się osoby, których nie można włączyć $\mathrm{w}$ akcję propagandową. Jest to zewnętrzny krąg ludzi, którzy pozostawali w bezpośrednich kontaktach $\mathrm{z}$ autorami Atlasu. Należy ich uwzględnić, ponieważ pozostawili po sobie wiele źródeł, stanowiących kontekst dla publikacji. Najczęściej byli oni politykami lub urzędnikami żywo zainteresowanymi przebiegiem wojny. Wśród nich są Hieronim Rozdrażewski, Marcin Kromer i Stanisław Reszka. Do grupy tej moglibyśmy też włączyć Antonia Martinellego, sekretarza nuncjusza, jeśli założymy, że to on przewiózł mapy do Rzymu. Martinelli był ponadto autorem włoskiej relacji o przebiegu działań wojennych w 1579 roku $^{62}$.

Oprócz tego w skład tej grupy wchodzą osoby pośrednio biorące udział w akcji propagandowej. Niektóre mapy i relacje trafiały później na tereny Rzeszy, choć nie wiemy, czy ich autorzy i dystrybutorzy pracowali na zlecenie kanclerza. Pewnym dopełnieniem oficjalnej propagandy było łacińskie epitalamium Daniela Hermanna (jesień 1579 roku) oraz niemiecka gazeta Georga Macka, obie prezentujące niemieckim czytelnikom okoliczności zdobycia Połocka. Także dla czytelników z Rzeszy Paweł Zumthorn przygotował kopię rysunku przedstawiającego oblężenie miasta. Autorem tego widoku był przypuszczalnie Frankus lub inny kartograf ${ }^{63}$. Ostatnią osobą, którą warto tu wymienić, jest Bazyli Hiacynt z Wilna, autor Panegyricus in excidium Polocense. Jego tekst był prawdopodobnie inspirowany przez kalwińskich Radziwiłłów. Utwór został bowiem zadedykowany hetmanowi Mikołajowi Radziwiłłowi „Rudemu”. Radziwiłłowie rywalizowali z Zamoyskim o chwałę zwycięzców. Na początku lat 80. XVI wieku włączyli się oni w akcję propagandową, której rezultatem jest kilka znakomitych utworów poetyckich, między innymi Jezda do

${ }^{62}$ Zob. A. Martinelli, Narratione del successo della guerra del re di Polonia contro al Moscovito l'anno 1579, предисловие, подготовка текста и перевод И.В. Дубровский, „Русский Сборник. Исследования по истории России” 21 (2017), s. 10-68. G. Franczak, Polotia recepta... (w przygotowaniu).

${ }_{63}$ Zob. K. Łopatecki, Ocena wiarygodności źródeł kartograficznych prezentujacych oblężenie Połocka z 1579 roku, „Terminus” 19 (2017), z. 4 (45), s. 759-795. 
Moskwy Jana Kochanowskiego (1583). Podobnie jak utwór Bazylego Hiacynta podkreślają one zasługi króla i Radziwiłłów, z pominięciem jednak roli kanclerza.

Pomiędzy wymienionymi postaciami istniały lub wytwarzały się sieci pośrednich lub bezpośrednich powiązań. Wiemy o tych związkach głównie z zachowanej korespondencji i dokumentów urzędowych. Pozwalają one naszkicować mapę relacji między uczestnikami i świadkami akcji propagandowej z 1579 i 1580 roku. Mapa ta pozwala uświadomić sobie skalę przedsięwzięcia.

\section{Podsumowanie}

Przeprowadzone badania nad propagandowym wymiarem Atlasu pozwalają sformułować następujące wnioski i hipotezy:

1. Atlas Księstwa Połockiego stanowił część większej akcji propagandowej polskiej kancelarii. Z tego powodu mapy Stanisława Pachołowieckiego należy rozpatrywać w szerszym kontekście powstałych wówczas tekstów. Są to teksty inspirowane przez kancelarię: edykty królewskie wydawane we wrześniu i październiku 1579 roku, mowa Nideckiego wydana w grudniu 1579 oraz wiersze Jana Kochanowskiego ze stycznia 1580 roku.

2. Wydanie Atlasu nie ma odpowiednika w historii polskiej propagandy politycznej w XVI wieku. Podobne publikacje kartograficzne inspirowane przez kancelarię koronną pojawiły się dopiero w następnym stuleciu. Nigdy nie przybrały one jednak postaci atlasu.

3. Atlas był przeznaczony przede wszystkim dla publiczności międzynarodowej (głównie we Włoszech i krajach niemieckojęzycznych). Dlatego kontekstem dla niego są również zagraniczne publikacje oparte na wspomnianych źródłach kancelaryjnych, między innymi wznowienie edyktów z Kolonii oraz wersje czeska i angielska Edictum de supplicationibus. 
4. Decyzja o publikacji map zapadła we wrześniu 1579 roku, ale dopiero w październiku lub listopadzie postanowiono wydać je za granicą. Równolegle zapadła decyzja o wznowieniu wszystkich dotychczasowych edyktów królewskich mówiących o przebiegu kampanii.

5. Osobą odpowiedzialną za publikację był przede wszystkim kanclerz Jan Zamoyski. On redagował mapy przed publikacją i faktycznie decydował o ich wydaniu.

6. Atlas został opublikowany jako kartograficzne dopełnienie prozatorskiej narracji o zdobyciu Połocka (Edictum de supplicationibus). Miał on ponadto podkreślać przynależność Księstwa Połockiego do Rzeczypospolitej.

7. Rękopiśmienne mapy zostały dostarczone do Rzymu na początku 1580 roku. Możliwe, że przywiózł je z Warszawy Antonio Martinelli, sekretarz nuncjusza papieskiego. Zostały one wydane drukiem najpóźniej w październiku tego roku, a egzemplarz Atlasu Księstwa Połockiego i być może innych map przesłano kanclerzowi Zamoyskiemu.

8. Osobą nadzorującą wydanie map w Rzymie był poseł polski Piotr Wolski, biskup płocki. Mapy zostały uzupełnione na miejscu przez kanonika Tomasza Tretera, wyrytowane i wydane przez jego współpracownika Giovanniego Battistę Cavalieriego.

9. Wydanie map było złożonym procesem logistycznym. Był on możliwy dzięki istniejącej sieci powiązań między uczestnikami akcji. Jednocześnie przygotowywanie publikacji wzmacniało i wytwarzało nowe połączenia w istniejącej już sieci. Sieć ta zapewniała skuteczność propagandzie Stefana Batorego. Źródła, czyli zachowane egzemplarze Atlasu, tłumaczenia i zagraniczne wydania edyktów oraz publikacje innych utworów popierających Batorego w wojnie z Moskwą, świadczą o sukcesie tego przedsięwzięcia.

10. Sukces ten zachęcił Batorego i Zamoyskiego do planu publikacji innych map z kampanii wojennej. Rezultatem tych decy- 
zji było udostępnienie części tych map Gerardowi Merkatorowi. Dwie z nich zostały wydane w jego atlasie w 1595 roku.

\section{Bibliografia}

\section{Źródła archiwalne}

Zumthorn P., oblężenie Połocka, Staatsarchiv Dresden, sygn. Schr. VII, F. 90. Nr. 17a.

\section{Źródła drukowane}

Akta Metryki Koronnej co ważniejsze z czasów Stefana Batorego 1576-1586. Z rozprawką na czele: O królu Stefanie jako myśliwcu, wyd. A. Pawiński, Warszawa 1882.

Archiwum Jana Zamoyskiego, kanclerza i hetmana wielkiego koronnego, t. 1: 15531579, wyd. W. Sobieski, Warszawa 1904.

Archiwum Jana Zamoyskiego, kanclerza i hetmana wielkiego koronnego, t. 2: 15801582, wyd. J. Siemieński, Warszawa 1909.

Basilius Hyacinthius Vilnensis, Panegyricus in excidium Polocense atque in memorabilem victoriam Stephani [...] ex potentissimo Moschorum Principe III. Calendis Septembris 1579 reportatam, Padova: Lorenzo Pasquato, 1580.

Caligari G.A., I.A. Caligarii nuntii apostolici in Polonia epistolae et acta 1578-1581, ed. L. Boratyński, Cracoviae 1915 (Monumenta Poloniae Vaticana, 4).

Edictum regium de supplicationibus ob rem bene adversus Moschum gestam, Kraków: Mikołaj Szarffenberg, 1579.

Edictum regium Svirense ad milites, ex quo causae suscepti in magnum Moscoviae ducem belli cognoscentur. Edictum regium de supplicationibus ob captam Polociam. Rerum post captam Polotiam contra Moscum gestarum narratio, Warszawa: Mikołaj Szarffenberg, 1579.

Edictum Serenissimi Poloniae Regis ad milites, ex quo causae suscepti in Magnum Moscoviae Ducem belli cognoscuntur. Item edictum eiusdem de suplicationibus ob captam Polociam habendis: cum epistola qua ordines ad comitia conuocantur et rerum post captam Polociam gestarum narratione. Hisce adiecta sunt quaedam de Magni Moscoviae Ducis genere, quod se nescio qua autoritate ab Augusto Caesare ducere iactitat, Köln, Maternus Cholinus, 1580.

Giardino de' poeti, Venezia: fratelli Guerra, 1583.

Graav H., Faber K., Francofordiae ac emporii Germaniae celeberiimi effigatio, 1552 (British Library, Maps KTop C-24-g18).

Gradowski F., Hodoeporicon Moschicum, Wilno: Daniel Łęczycki, 1582. 
Hakluyt R., The principal Navigations, Voyages, Traffiques and Discoveries of the English Nation, vol. 1, London 1809.

Heidenstein R., De bello Moscovitico commentatorium libri sex, Kraków: Drukarnia Łazarzowa, 1584.

Jenkinson A., Nova absolutaque Russiae Moscoviae et Tartariae descriptio, London: Clement Adams, 1562. Jedyny zachowany egzemplarz editio princeps: Biblioteka Uniwersytetu Wrocławskiego, sygn. 9590-IV.C.

Kochanowski J., Ad Stephanum Bathorrheum regem Poloniae inclytum Moscho debellato et Livonia recuperata epinicion, Kraków: Drukarnia Łazarzowa, 1583.

Kochanowski J., Jezda do Moskwy, Kraków: Drukarnia Łazarzowa, 1583.

Kochanowski J., Jezda do Moskwy, w: J. Kochanowski, Poematy okolicznościowe, oprac. R. Krzywy, Warszawa 2018.

Kochanowski J., Pieśni trzy... O wzięciu Połocka. O statecznym słudze R.P. O uczciwej matżonce, Warszawa 1583, http://www.polona.pl/dlibra/doccontent2?id=85\&f rom $=$ editionindex \&from $=-3$ search \&dirids $=20 \&$ lang $=\mathrm{pl}($ dostęp: 28.10 .2018$)$.

Korespondencja Hieronima Rozrażewskiego, t. 1: 1567 - 2 VII 1582, wyd. P. Czeplewski, Toruń 1937.

Mack G. st., Die Eroberung von Polotsk in Litauen, Nürnberg 1579, Biblioteka Książąt Czartoryskich w Krakowie, sygn. XV-R. 6813.

Martinelli A., Narratione del successo della guerra del re di Polonia contro al Moscovito l'anno 1579, предисловие, подготовка текста и перевод И.В. Дубровский, „Русский Сборник. Исследования по истории России” 21 (2017), s. 10-68.

Novina jista a pravdiva o dobyti znameniteho zamka a pevnosti velihego mesta [...] Polocka, Praha 1580.

Relacje nuncjuszów apostolskich i innych osób o Polsce od roku 1548 do 1690, t. 1, wyd. E. Rykaczewski, Berlin-Poznań 1864.

Reszka S., De rebus gestis Stephani I regis Poloniae [...] contra Magnum Moschorum Ducem narratio, Roma: heredes Antonii Bladii, 1582.

Rymsza A., Deketeros akroama, Wilno: Daniel Łęczycki, 1585.

Strubicz M., Brevis atque accurata Livonioe Ducatus descriptio historico-geographica, ed. J.L. Diezius, Amsterdam: Abraham Strander, 1727.

A True reporte of the taking of the great towne and castell of Polotzko by the King of Polonia with the manner of the assaults, batteries, undermininges, skirmishes and fyreworkes, that were there vsed from the 11 of August to the 30 of the same month 1579, [London: s.n.], 1579.

Viridarium poetarum, Venezia: Joannes Gryphius, 1583.

$Z$ dworu Stanistawa Hozjusza. Listy Stanisława Reszki do Marcina Kromera 15681582, przeł., wstęp i komentarze J.A. Kalinowska, Olsztyn 1992. 


\section{Opracowania}

Дубровский И.В., Латинские рукописи сочинений Альберта Шлихтинга, „Русский сборник. Исследования по истории России” 18 (2015), s. 74-217.

Дубровский И.В., Новые документы о России Ивана Грозного, „Русский сборник. Исследования по истории России" 11 (2012), s. 26-41.

Дубровский И.В., Новые документы по истории отномений России и Италии при Иване Грозном, „Русский сборник. Исследования по истории России” 14 (2013), s. 7-12.

Alexandrowicz, S., Kartografia Wielkiego Księstwa Litewskiego od XV do połowy XVIII wieku, Warszawa 2012.

Awianowicz B., Wstęp, w: A. Patrycy Nidecki, Trzy mowy gratulacyjne z okazji zwycięstwa nad Moskwicinami, oprac. B. Awianowicz, Warszawa 2016, s. 5-32.

Benedict Ph., Graphic History. The Wars, Massacres and Troubles of Tortorel and Perrissin, Genève 2007.

Brunelli G., Gallio Tolomeo, w: Dizionario Biografico degli Italiani, vol. 51, Roma 1998, http://www.treccani.it/enciclopedia/tolomeo-gallio_\%28Dizionario-Biografico\%29/ (dostęp: 1.06.2018).

Buchwald-Pelcowa P., Dawne wydania dzieł Jana Kochanowskiego, Warszawa 1993.

Buczek K., Dorobek kartograficzny wojen Stefana Batorego, „Wiadomości Służby Geograficznej" 8 (1934), z. 3, s. 3-15.

Buczek K., Kartografia polska w czasach Stefana Batorego, „Wiadomości Służby Geograficznej" 7 (1933), z. 2, s. 69-121.

Chrzanowski T., Działalność artystyczna Tomasza Tretera, Warszawa 1984.

Evans J., The Silver Medal or Map of Sir Francis Drake, „The Numismatic Chronicle and Journal of the Royal Numismatic Society", Fourth Series, 6 (1906), s. $348-350$.

Franczak G., Filologia mapy. Badanie dawnej kartografii metoda krytyki tekstu na przykładzie toponimii mapy Księstwa Połockiego S. Pachołowieckiego z 1580 roku, „Terminus” 19 (2017), z. 1 (42), s. 193-252.

Franczak G., Polotia recepta. Mapa Księstwa Połockiego jako tekst propagandowy (w przygotowaniu).

Franczak G., Rzymski łącznik. Giovanni Battista Cavalieri (1525-1601), rytownik Hozjusza i Tretera (w przygotowaniu).

Franczak G., Wstęp, w: W. Neothebel, Acrostichis własnego wyobrażenia kniaża wielkiego moskiewskiego, oprac. G. Franczak, Warszawa 2016, s. 5-66.

Gömöry G., The Polish Swan Triumphant: Essays on Polish and Comparative Literature from Kochanowski to Norwid, Newcastle upon Tyne 2013.

Grala H., Wokół dzieła i osoby Alberta Schlichtinga (przyczynek do dziejów propagandy antymoskiewskiej w drugiej połowie XVI w.), „Studia Źródłoznawcze” 38 (2000), s. 35-51. 
Harley J.B., Maps, Knowledge, and Power, w: idem, The New Nature of Maps. Essays in the History of Cartography, ed. by P. Laxton, introd. J.H. Andrews, Baltimore-London 2001, s. 51-81.

Jurkowlaniec G., Sprawczość rycin. Rzymska twórczość graficzna Tomasza Tretera i jej europejskie oddziaływanie, Kraków 2017.

Kappeler A., Ivan Groznyj im Spiegel der ausländischen Druckschriften seiner Zeit: ein Beitrag zur Geschichte des westlichen Russlandbildes, Bern-Frankfurt am Main 1972.

Kawecka-Gryczowa A., Dzieje „Drukarni latającej”. Działalność i wędrówki, „Rocznik Biblioteki Narodowej" 7 (1971), s. 355-376.

Kozica K., Charakterystyka prac kartograficznych Stanisława Pachołowieckiego (1580), „Terminus” 19 (2017), z. 1 (42), s. 37-59.

Łopatecki K., Oblężenie i zdobycie warownej twierdzy połockiej przez Najjaśniejszego Króla Polski Stefana - wykorzystanie kartografii podczas planowania taktycznego, „Terminus” 19 (2017), z. 4 (45), s. 705-758.

Łopatecki K., Ocena wiarygodności źródeł kartograficznych prezentujących oblężenie Połocka $z 1579$ roku, „Terminus” 19 (2017), z. 4 (45), s. 759-795.

Łopatecki K., Rola map i planów w działaniach taktycznych wojsk polskich i litewskich do poczatku panowania Stefana Batorego, „Terminus” 19 (2017), z. 3 (44), s. 609-663.

Łopatecki K., Ryciny prezentujace kampaniępołocka 1579 roku jako jednolita kompozycja kartograficzna, „Terminus” 19 (2017), z. 1 (42), s. 157-191.

Łopatecki K., Wykorzystanie map w działaniach strategicznych do 1586 roku w Koronie $i$ Wielkim Księstwie Litewskim, „Terminus” 19 (2017), z. 3 (44), s. 511-566.

Marchesani P., La Polonia nella storiografia italiana dei secoli XVI-XVII: I clichés ideologici e la loro evoluzione, „Europa Orientalis” 5 (1986), s. 203-231.

Mears N., Queenship and Political Discourse in the Elizabethan Realms, Cambridge 2005.

Morawski K., Andrzej Patrycy Nidecki. Jego życie i dzieła, Kraków 1892.

Niedźwiedź J., Atlas Księstwa Połockiego Stanisława Pachołowieckiego (1580): propaganda, genologia i tworzenie wiedzy geograficznej, „Terminus” 19 (2017), z. 1 (42), s. 127-155.

Niedźwiedź J., Atlas Księstwa Połockiego - wprowadzenie, „Terminus” 19 (2017), z. 1 (42), s. 1-18.

Niedźwiedź J., Mercator's Lithuanian-Russian Borderlands. Russiae pars amplificata (1595) and Its Polish Sources, „Imago Mundi” (w druku).

Niedźwiedź J., Źródła, konteksty i okoliczności powstania Ody o zdobyciu Połocka Jana Kochanowskiego, „Terminus” 18 (2016), z. 4 (41), s. 359-400.

Nowak-Dłużewski J., Okolicznościowa poezja polityczna w Polsce. Pierwsi królowie elekcyjni, Warszawa 1969.

Obremski K., Wstęp, w: Volsciana. Katalog renesansowego księgozbioru Piotra Dunin-Wolskiego, biskupa płockiego, oprac. A. Obrębski, Kraków 1999, s. 5-7. 
Piechnik L., Początki Akademii Wileńskiej 1570-1599, foreword J.W. Woś, Roma 1984.

Piotrowski J., Dziennik wyprawy Stefana Batorego pod Psków, wyd. A. Czuczyński, Kraków 1894.

Pollak M., Cities at War in Early Modern Europe, New York 2010.

Putten J. van, Networked Nation. Mapping German Cities in Sebastian Münster's 'Cosmographia', Leiden-Boston 2017.

Randall D., Credibility in Elizabethan and Early Stuart Military News, London-New York 2015.

The Taking of Polack - 1579. Elizabethan Newssheet, „The Journal of Belarusian Studies" 1, (1965), no. 1, s. 16-22. 


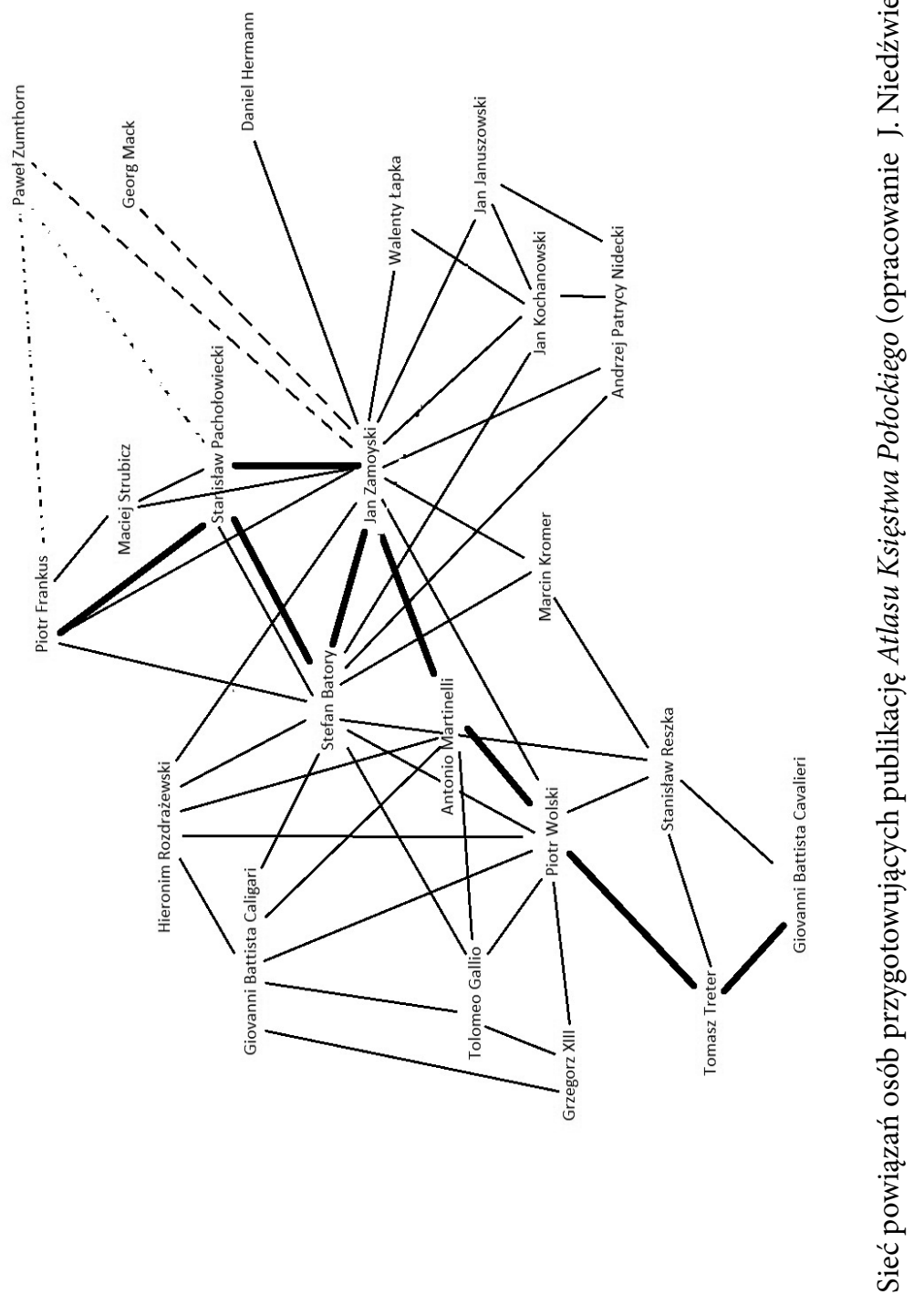

